\title{
Critical Assessment of Development of a Modernizing Society in Eastern Europe: Latent Risks for Social Inclusion
}

\author{
Yuriy B. Savelyev* \\ National Taras Shevchenko University of Kyiv \\ 60 Volodymyrska Str., Kyiv, 01601, Ukraine
}

Received 11.03.2014, received in revised form 16.05.2014, accepted 17.09.2014

The capability approach has emphasized human freedom and possibility of choice over various alternatives as a person's capability set (Foster and Sen, 1997). Consequently, a rise of capabilities is a core of human development (Sen, 1999) and essential part of modernization process (Welzel, Inglehart and Klingemann, 2003). The paper suggests the capabilities model of social inclusion and attempts to use such an approach to gauge human development of a modernizing society as well as reveal hidden risks for inclusion. It is argued that despite rapid economic growth, the actual increase of real disposable income per capita and improvement of Human Development Index in Ukraine since the end of the 1990's, the capabilities of its citizens have been seriously jeopardized. Ukraine fails to keep pace with other societies of the region (except Moldova) although the levels of development of Eastern European countries were very similar 20 years ago. This implies the growing gap in social actors' capabilities between the national states within the region.

Keywords: social inclusion, modernization, human development, capabilities, Eastern Europe, Ukraine.

Research area: 22.00.00-sociology.

\section{Introduction}

In present-day global world Eastern European societies are too small to be considered important on an international scale, while social scientists' attention is concentrated on the big rising powers of the former 'third-world'. However, much of the profound changes that have occurred in the world during last two decades were triggered by the region. It is exactly Central and Eastern Europe where the epicentre of transformation was located and social movements emerged that undermined socialist regimes 25 years ago. The Eastern Bloc collapsed which ended the age of a bipolar world, boosted globalization and eventually led to the contemporary global state of play.

Those changes were immediately reflected by sociologists. At that time theories of neomodernization of post-socialist societies became themainstreamideaalongwithanoptimisticproject of transformation of Eastern European countries into Western like democratic market economy society. Nevertheless, despite institutional and cultural similarity, a developmental track in the region was apparently different which resulted

(C) Siberian Federal University. All rights reserved

* Corresponding author E-mail address: yursave@yahoo.com 
into different economic levels and quality of life which were achieved by various countries. This experience of Eastern Europe raises once again a question of plausibility of modernization and possible ways towards modernity. Contemporary sociology lacks modernization theory which would provide a tool to find an adequate answer. As W.Knöbl noted 'there is no stable, empirically grounded theory... All there is... some sort of modernization discourse, some vague ideas about possible developmental paths of contemporary societies.' (Knöbl, 2003: 105)

This paper suggests using a modernization model based on the capability approach to gauge human development of a modernizing society in Eastern Europe. The capability approach has emphasized human freedom and possibility of choice over various alternatives as a person's capability set and the actual functioning combination (Foster and Sen, 1997). Within the approach the increase of capabilities is a core of human development process (Anand and Sen, 1994; Sen, 1999). However, this also implies that even in the situation of equal rights and opportunities not all people may be able to choose options of which they are capable. Therefore, modernization can be considered a process that increases capabilities and enhances inclusion of social actors. Using the capability approach to assess modernization of a society would reveal hidden risks for exclusion and explicate indicators of inequality.

First, the paper provides an overview of problems of post-socialist development and modernization in Eastern Europe in the past two decades. Human development is considered a benchmark of modernization. Based on threeelement modernization and human development model suggested by Welzel, Inglehart and Klingemann (2003) I argue that social inclusion is related to both the options application, which is the freedom to choose in the capability approach, and the choice application, which is the actually chosen, is important dimension of modernization. Such a theoretical framework of social inclusion may be a contribution into application of the capability approach in sociology to expose developmental problems, inequality and exclusion which would enhance the assessment of the needs of the vulnerable groups.

Second, the paper focuses on Ukraine as a case of the post-socialist modernizing society. It is asserted that an optimistic prospect, which appeared after social and economic disruption of the 1990's in Eastern Europe, was not uniformly distributed for different countries. Compared to the region, Ukraine fails to keep pace with either Eastern or Western neighbours except Moldova although the levels of development of most Eastern European countries were very similar 20 years ago and Ukraine used to have the median of regional human development value. This implies the growing gap in capabilities between the national states within the region.

Third, the research demonstrates limitations of indicators of official statistics, data from traditional surveys and Human Development Index (HDI) linking these indicators data to the set of capabilities. I will show that despite positive dynamic in economic growth, average income and human development in Ukraine in the 2000's, capabilities of the vast majority of its citizens have been jeopardized. In particular, the capability for housing, which was still very poor in 1998, dramatically plunged in the 2000's.

As a method of research I use original as well as secondary data analysis comparing trends of various existing indicators including HDI, GDP PPP per capita, Gini index, national and regional income and housing statistics, monthly average wages, price trends on the secondary residential market, self-reported data from the surveys of the Institute of Sociology of the National Academy of Sciences (NAS) of Ukraine. The sources of 
the study comprise statistical data of the State Statistics Committee of Ukraine, United Nations Human Development Reports, the International Monetary Fund data, Association of Real Estate Specialists of Ukraine (ASNU), annual surveys of the Institute of Sociology of the NAS of Ukraine 'Ukrainian Society: Sociological Monitoring 1994-2010’.

\section{Problem background and theoretical framework}

Sociologists (Esping-Andersen, 2007) and development economists (Yusuf et al., 2009; Sachs, 2008) emphasize that a critical problem for contemporary society is inequality, which persists and even has been growing in various countries as well as in the global system overall. A challenging question for social scientists is about varieties of social existence and alternatives of social, economic and cultural development (ISA, 2006). If modernity emerged in Western (NorthernAtlantic) civilization and is spontaneous in terms of its culture and societal evolution, Ukraine and many other post-socialist countries are societies with 'catching-up development' which determines numerous problems of their growth and makes an issue of inequality more acute.

Since the Eastern Bloc collapsed, theories of neo-modernization of post-socialist countries became the mainstreamidea. An optimistic project of transformation of post-socialist societies into western capitalist liberal model was conceived. P.Sztompka pointed out that since 1989 theory of modernization has focused on post-communist countries attempts to 'return to Europe', join the modern Western civilization (Sztompka, 1996: 101).

Subsequently there has been criticism on modernization of post-communist countries (Allardt, 2002; Kapustin, 2003). It wasn't a smooth process and in a number of cases desired modernization turned into 'the unprecedented demodernization of a twentieth-century country' when society was pulled 'backward to a premodern era' (Cohen, 2001: 45, 169). However, despite common difficulties there are apparent differences in the paths of development of former socialist countries in the region.

After the collapse of Eastern Bloc and the Soviet Union in the beginning of the 1990's Central and Eastern Europe fell into two clusters with different development tracks. While three former Soviet Republics (Belarus, Moldova and Ukraine) were involved into post-soviet integration project (CIS) maintained by Russian Federation, the other three former Soviet republics (Estonia, Latvia and Lithuania) with the rest of Central and Eastern European societies became determined to complete European integration.

Since the middle of the 1990's modernization of Central and Eastern Europe has been 'predominantly understood in terms of a gradual incorporation of the post-communist societies into the European project. This process is then mostly read as convergence in legal, institutional, and political terms' (Blokker, 2005: 515). This has redefined Eastern Europe radically.

Recent enlargements of the European Union have left three Eastern European countries - Belarus, Moldova and Ukraine - in a specific zone that presently embodies European civilization borderland. Those countries share the same features: they used to be a part of imperia (Russian, Austro-Hungarian and then Soviet) and may be considered as post-colonial societies; they were involved in the Communist project of accelerated modernization that was an alternative to the Western one; nowadays they are located between the EU and Russian Federation and experience integrative process from both sides.

After the EU enlargements Eastern Europe doesn't even exist as an integral region. A criterion of belonging to the European project is much more important than geographic vicinity. 
Present-day Eastern Europe, definition of which has always had connotation of a peripheral region, basically narrowed to three countries only: Belarus, Moldova and Ukraine.

At this point of time there are two peripheral regions in Europe as a civilization. The first is mentioned above Eastern Europe (or what has left from it), the second - 'Western Balkans' (Croatia, FYR Macedonia, Albania, Bosnia and Herzegovina, Montenegro and Serbia including Kosovo). ${ }^{1}$ Nevertheless, these two regions differ significantly. While societies of Western Balkans committed to integration process and either have been granted candidate country status or recognized as potential candidate countries (European Commission, 2007), Belarus, Moldova and Ukraine are very far from that.

Moreover, the region of Western Balkans is radically different from Eastern Europe. Western Balkans countries are located on the frontiers of contemporary European project which has been expanding its spatial body. Those societies do not have an alternative to integration. Very probably, sooner or later they will be incorporated to the project. This is a just a matter of their readiness that simply requires time. In contrast to them, Belarus, Moldova and Ukraine are the borderland which is located between European Union, which represents integration on the basis of common liberal values Western post-industrial marketeconomy democracy, and Russian Federation, which often claims itself to be exceptional 'Eurasian' way of development. Therefore, in the case of Eastern Europe there is an alternative to integration. There are three possible ways of development for Eastern European borderland: one of integration options will be implemented (either European or Russian), the region will be conserved as the borderland which is utilized as a buffer from both sides.

After disruption of the 1990's a period of rapid economic growth began in the region which gave an optimistic prospect. However, Moldova and Ukraine (Belarus has better performance close to recent EU members Bulgaria and Romania) still have the lowest ranks of GDP per capita and Human Development Index (HDI) in Europe (Human Development Report, 2011). Russian Federation and Belarus have not succeeded in development of democratic institutions. Ukrainian democracy is flawed. More recently Russian and Ukrainian political leaders claimed a specific (alternative to Western model that other Eastern European societies are trying to follow) way of development emphasizing technical modernization and economy based on innovations. ${ }^{2}$ The question is whether such a way of modernization can be efficient. Hence, it is important to gauge development beyond economic growth (Stiglitz, Sen, Fitoussi, 2009).

Since 1990 HDI has been widely used for this purpose. However, since it was introduced, HDI has been criticized as 'conceptually weak and empirically unsound, involving serious problems of non-comparability over time and space' measure (Srinivasan, 1994: 241). R.Sugden (1993) questioned HDI as an operational tool. In recent 20 years HDI methodology has been advanced and significant contributions into conceptual development and operationalization have been made (e.g. Nussbaum and Sen, 1993; Martinetti, 2000; Kuklys, 2005; Comim et al., 2008). HDI is rooted in the capability approach that besides cross-country comparisons allows deeper understanding of a process and factors of modernization focusing on the increase of capabilities as a core of human development. Employing the capability approach, Welzel, Inglehart and Klingemann (2003) suggested three-element modernization model comprising individual resources (objective means of choice), emancipative cultural values (motives of choice) and institutional rules (effective rights to human 
choice). In this model the focus is set, first, on the increasing role of emancipative and selfexpression values due to the growth of resources, second, on the linkage of emancipative values as the motives of choice to effective freedom rights and efficient democratic institutions. The model, however, is limited to the linear relationships of resources and values. It does not reveal differences in the access to the resources, participation and the ways of securing the access and choice.

According to A.Sen, the increase of capabilities is a twofold set comprising the options application, which is the freedom to choose, and the choice application, which is the actually chosen (Foster and Sen 1997). Ways and means of securing human freedom and possibility of choice are crucial and require various forms of involvement of social actors in life of society, i.e. their social inclusion. A rise in capabilities is not possible without inclusion of social actors, for it accounts for their choice application. That is why social inclusion is considered a crucial means of human development (Andjelkovič et al., Анджелкович 2011). On the other hand, lack of social inclusion also limits freedom to choose.

Therefore, an elaborated model of human development and modernization should embrace a dimension of social inclusion. Theoretical contributions (Parsons, 1966; 1977; Alexander, 1980; Wilson, 2006; Lamont, 2009; Acemoglu and Robinson, 2012) clearly demonstrate that social inclusion is related to integration of social system, to social institutions, social and cultural capital and ultimately to various forms of incorporation of different social groups into a core society. Social inclusion does not exclusively refer to particular deprived groups but is an important aspect which 'makes societies successful' (Lamont, 2009: 151). Social relationships of various types are built on relative capabilities allocated for social agents and groups which determine their actual choices.
The capabilities model of social inclusion may be an analytical tool in understanding the ways of securing human freedom and possibility of choice, and, consequently, development of a society and modernization. This model comprises:

1. The means of providing choice (the capabilities set) and securing access to the resources; fair and efficient system of redistribution of resources (Dworkin, 2002).

2. Recognition, which determines social esteem of 'abilities and activities' and eventually 'contribution to social reproduction' of different social groups (Honneth, 2001: 54-55).

3. Participation which reflects the capabilities for social interaction (Fraser, 2007).

4. Values as motives of action and choice (Schwartz et al., 2001; Welzel, Inglehart and Klingemann, 2003).

5. Effective democracy and rights as institutional means of securing choice (Welzel, Inglehart and Klingemann, 2003).

The combination of all elements accounts for the options application as well as for the choice application. Consequently, modernization is a process that expands capabilities and enhances social inclusion.

In this paper we focus on the issue of the relative access to the resources studying the case of a modernizing society in Eastern Europe in comparative perspective with an attempt to reveal hidden risks for inclusion and assess human development via selected specific aspect of the capabilities set.

\section{Trends of Human Development in Eastern Europe}

This section aims to investigate the trends of human development in Eastern European 
countries and identify possible differences in capabilities between the national states within the region and, in particular, between Ukraine and its neighbour countries.

If we look at human development and economic growth of Ukraine in recent 20 years, we will see that decline in 1990's followed by rapid and persistent growth since 1999 till global economic crisis in 2008. Such growth is supposed to increase the capabilities of social agents. However, estimation of such an increase would be more informative if it is related to the context of societies with similar development path and corresponding level of the capabilities in the initial point of comparison.

In 1990 Central and Eastern European countries could be divided into 4 clusters by two dimensions. However, if ignore a factor of location, which is important because Soviet republics didn't have many institutions of an independent state and experienced deeper crisis in 1990's, all 13 countries fall into 2 groups of less developed (4 countries) and more developed ( 9 countries) based on UNDP criterion HDI equals 0.800 or above. Five out of nine countries in a more developed cluster were the part of the Soviet Union.

Before the collapse of the Eastern block in 1990 there was no significant difference in HDI value between Ukraine and the majority of Eastern European countries. In fact, Ukraine's HDI value of 0,809 matched the median in the selected set of 13 countries. ${ }^{3}$ As it follows from Table 1, six countries had higher value than Ukraine and six lower. Ukraine's value was even slightly above the mean of 0,806 in the set.

However, Slovenia and Czech Republic, which historically had been closer to more developed core of European civilization, had higher level of development among others $(0,851$ and 0,845). Among Soviet countries Lithuania demonstrated better performance with the value of 0,827. Estonia, Russian Federation, Ukraine and Latvia were approximately at the same level with Poland and Hungary. Soviet Belarus, Bulgaria and Romania constituted a cluster of less developed societies. Moldova had the lowest HDI $(0,740)$ and was considerably behind.

Table 1. HDI of Central and Eastern European countries in 1990 - 2005

\begin{tabular}{|c|c|c|c|c|c|}
\hline HDI Rank 2005 & Country & 1990 & 1995 & 2000 & 2005 \\
\hline 27 & Slovenia & 0,851 & 0,857 & 0,891 & 0,917 \\
\hline 32 & Czech Republic & 0,845 & 0,854 & 0,866 & 0,891 \\
\hline 36 & Hungary & 0,813 & 0,817 & 0,845 & 0,874 \\
\hline 37 & Poland & 0,806 & 0,822 & 0,852 & 0,870 \\
\hline 43 & Lithuania & 0,827 & 0,791 & 0,831 & 0,862 \\
\hline 44 & Estonia & 0,813 & 0,792 & 0,829 & 0,860 \\
\hline 45 & Latvia & 0,804 & 0,771 & 0,817 & 0,855 \\
\hline 53 & Bulgaria & 0,794 & 0,785 & 0,800 & 0,824 \\
\hline 60 & Romania & 0,777 & 0,772 & 0,780 & 0,813 \\
\hline 64 & Belarus & 0,790 & 0,755 & 0,778 & 0,804 \\
\hline 67 & Russian Federation & 0,815 & 0,771 & 0,782 & 0,802 \\
\hline 76 & Ukraine & 0,809 & 0,756 & 0,761 & 0,788 \\
\hline 111 & Moldova & 0,740 & 0,684 & 0,683 & 0,708 \\
\hline
\end{tabular}

Source: HUMAN DEVELOPMENT REPORT 2007/2008. P. 229-230 
Table 2. Clusters of Central and Eastern European countries in 1990.

\begin{tabular}{|l|c|c|c|}
\hline \multicolumn{1}{|c|}{ Location/HDI } & More developed (HDI $\geq 0,800)$ & Less developed (HDI <0,800) & $\begin{array}{c}\text { Total number } \\
\text { of countries }\end{array}$ \\
\hline Soviet & $\begin{array}{c}5 \\
\text { Lithuania, Estonia, Latvia, } \\
\text { Russian Federation, Ukraine }\end{array}$ & $\begin{array}{c}2 \\
\text { Belarus, Moldova }\end{array}$ & 7 \\
\hline Non-Soviet & $\begin{array}{c}4 \\
\text { Slovenia, Czech Republic, } \\
\text { Hungary, Poland }\end{array}$ & $\begin{array}{c}2 \\
\text { Bulgaria, Romania }\end{array}$ & 6 \\
\hline Overall & 9 & 4 & 13 \\
\hline
\end{tabular}

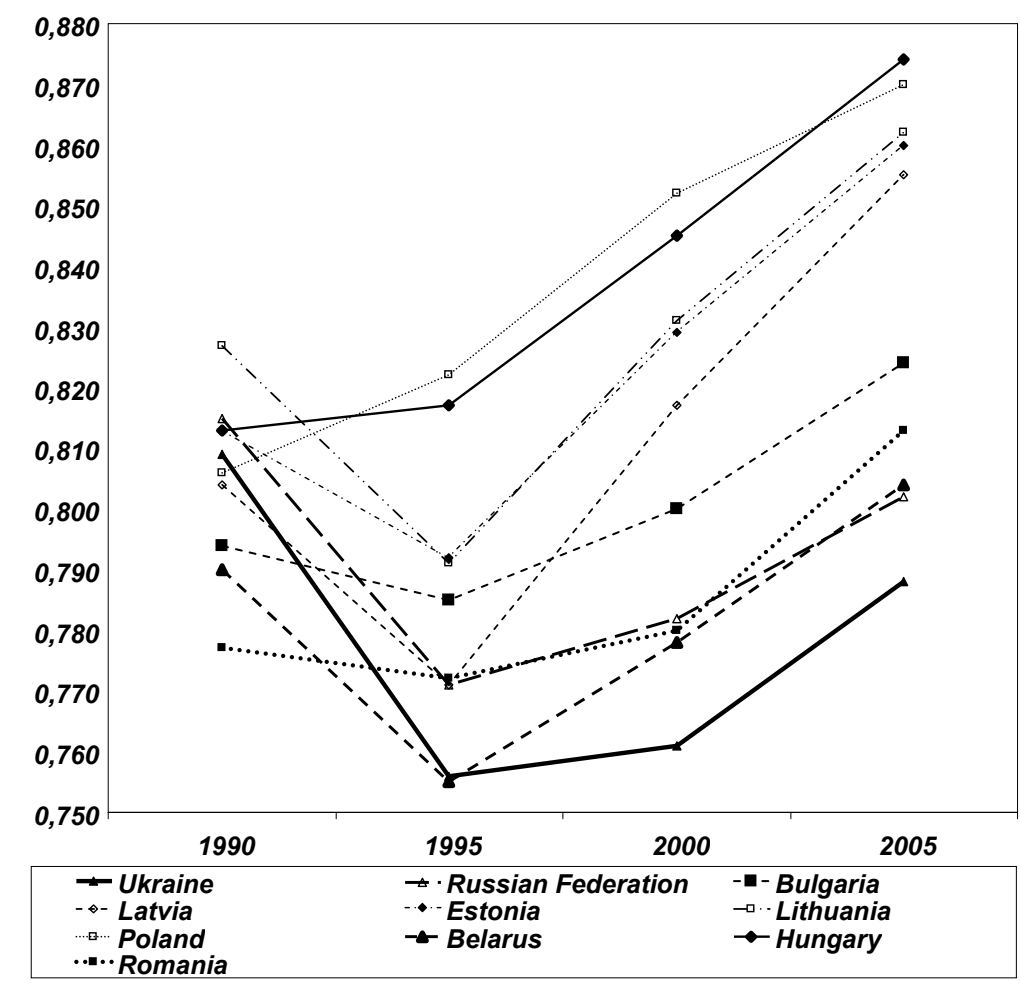

Fig. 1. HDI trends for 10 Central and Eastern European countries in 1990-2005

Figure 1 demonstrates dynamic in human development of post-socialist countries in Eastern European region. The Figure doesn't include Slovenia and Czech Republic that are above the mainstream and Moldova that is much lower. Moldova constitutes a separate case; it was an agricultural republic of the Soviet Union. In addition due to separatist movement it lost the most developed part Transnistria (Pridnestrovie) in the beginning of the 1990's. That is why even compared to other post-soviet countries that were pulled backward after the USSR collapsed Moldova can be estimated at a very low level of development - 111 HDI rank (Human Development Report, 2005).

The Fig. 1 shows that Poland and Hungary didn't experience such a fall in contrast to postsoviet countries. Lithuania, Estonia and Latvia did 
have a drop as well as other Post-Soviet countries. However, they quickly recover after 1995. Latvia experienced a huge HDI slump in the middle of 1990's but developed progressively.

Bulgaria and Romania had moderate decrease from 1990 till 1995. Their HDI trends were very similar to the HDI trends of Russian federation and Belarus from 1995 till 2000, but from 2000 HDI began growing much faster so that even Romania passed Belarus and Russian Federation by 2005 . In contrast to 1990, Ukraine's HDI value in $2005(0,788)$ was much lower of median of the set of 13 countries $(0,855)$ and even lower of the $1^{\text {st }}$ quartile $(0,836)$. Ukraine had the largest slump and is backward except Moldova which is not in the Figure because of the extremely low HDI value. Notably, both Ukraine and Belarus had virtually identical minimum of HDI in 1995, unlike Ukraine Belarus experienced much faster increase of HDI which approached the value of 1990 in 2000 and exceeded it considerably in 2005. Belarus also improved its relative position in the country set from 1990 to 2005.

Figure 2 shows the difference between six post-soviet countries clearly. Lithuania, Estonia and Latvia were by HDI at the same level of development with Russian Federation and Ukraine in 1990. HDI dropped dramatically for all countries by 1995. By 2005 six countries formed two distinct clusters. Three Baltic States which are involved in the European project have considerably higher HDI.

Among three Post-Soviet states Ukraine demonstrates a typical pattern. Russian Federation's HDI progress is predominantly a result of growing GDP per capita. The latter is maintained increasingly by fuel and energy industry. Belarus has better performance than

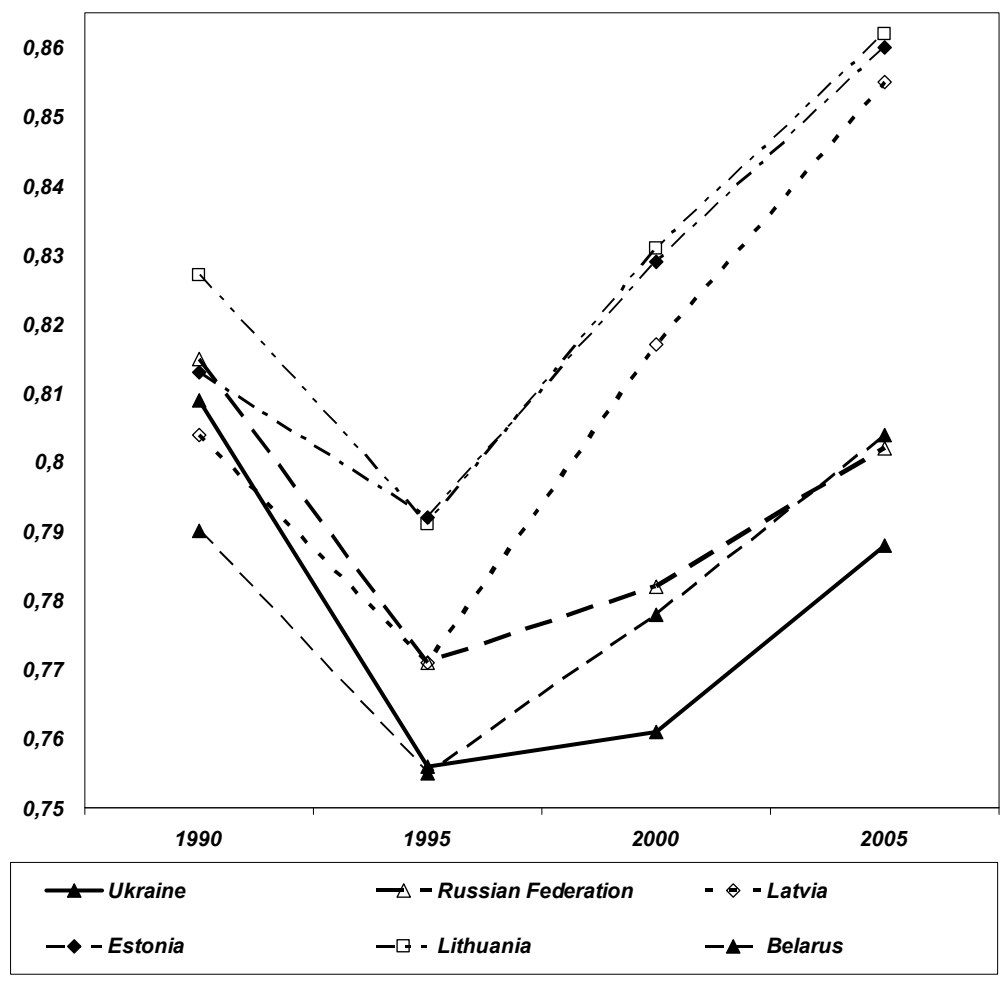

Source: HUMAN DEVELOPMENT REPORT 2007/2008. P. 229-230

Fig. 2. HDI trends for 6 Post-Soviet countries in 1990-2005 
Ukraine and Russian Federation since 1995. This is the only country among these three that exceeded HDI value of 1990. It can be explained by existing efforts of authoritarian regime. Such a regime is capable of mobilizing resources for a certain period of time.

Above we considered HDI trends of selected societies that gave the opportunity to draw comparisons. However, it is more important to analyze development of Central and Eastern European countries in the broader context to understand their developmental track.

The US development is suggested to be a scale for changes in the modern world. The US is the largest Western society with the biggest economy. It fully embodies values and principles of market-economy democracy. Nonetheless the US doesn't have the highest HDI among the most developed countries. Below data will present HDI trends of selected countries compared against US HDI trend between 1990 and 2005. This also allows finding relative development shift for each society taking into account initial country's position in 1990.
All Central and Eastern European countries that are the EU member-states (EU8) demonstrate positive dynamics in relation to the US. They all improved their HDI ratio. The biggest improvement demonstrate Slovenia (3,82 \%) and Poland (3,78\%). Latvia demonstrates the best relative result among post-soviet A8 countries $(2,42 \%)$, although its absolute HDI value is the smallest.

Bulgaria and Romania also have HDI growing better that the US. Although improvement is less significant: $0,25 \%$ and $0,94 \%$ accordingly. Bulgaria has the lowest value among all ten Central and Eastern European countries. Overall three countries have relative change range below $1 \%$ (Bulgaria, Romania and Lithuania).

Adding Bulgaria and Romania to the aggregate list of EU8 and EU2 makes the mean of relative range value a bit smaller $-0,0211$, $\sigma^{2}=0,0002$.

The state of affairs in the post-soviet societies is absolutely different. All countries as well as Russian Federation have negative dynamic in relation to the US.

Table 3. Relative HDI change in Central and Eastern European countries (EU8) in 1990/2005

\begin{tabular}{|c|c|c|c|c|c|c|}
\hline $\begin{array}{c}\text { HDI Rank } \\
2005\end{array}$ & Country & $\begin{array}{c}\text { HDI } \\
\text { original value } \\
1990\end{array}$ & $\begin{array}{c}\text { HDI } \\
\text { original value } \\
2005\end{array}$ & $\begin{array}{c}\text { Country's } \\
\text { HDI/United } \\
\text { States' HDI } \\
\text { ratio 1990 }\end{array}$ & $\begin{array}{c}\text { Country's } \\
\text { HDI/United } \\
\text { States' HDI } \\
\text { ratio 2005 }\end{array}$ & $\begin{array}{c}\text { Relative } \\
\text { change range } \\
1990 / 2005\end{array}$ \\
\hline 12 & $\begin{array}{c}\text { Point of } \\
\text { reference } \\
\text { (US) }\end{array}$ & 0,919 & 0,951 & 1,000 & 1,000 & 0,0000 \\
\hline 27 & Slovenia & 0,851 & 0,917 & 0,926 & 0,964 & 0,0382 \\
\hline 32 & $\begin{array}{c}\text { Czech } \\
\text { Republic }\end{array}$ & 0,845 & 0,891 & 0,919 & 0,937 & 0,0174 \\
\hline 36 & Hungary & 0,813 & 0,874 & 0,885 & 0,919 & 0,0344 \\
\hline 37 & Poland & 0,806 & 0,870 & 0,877 & 0,915 & 0,0378 \\
\hline 43 & Lithuania & 0,827 & 0,862 & 0,900 & 0,906 & 0,0065 \\
\hline 44 & Estonia & 0,813 & 0,860 & 0,885 & 0,904 & 0,0197 \\
\hline 45 & Latvia & 0,804 & 0,855 & 0,875 & 0,899 & 0,0242 \\
\hline
\end{tabular}

Mean $=0,0255 ; \sigma 2=0,0001$

Source: HUMAN DEVELOPMENT REPORT 2007/2008. P. 229-230 
Table 4. Relative HDI change in Bulgaria and Romania (EU2) in 1990/2005

\begin{tabular}{|c|c|c|c|c|c|c|}
\hline $\begin{array}{c}\text { HDI Rank } \\
2005\end{array}$ & Country & $\begin{array}{c}\text { HDI } \\
\text { original value } \\
1990\end{array}$ & $\begin{array}{c}\text { HDI } \\
\text { original value } \\
2005\end{array}$ & $\begin{array}{c}\text { Country's } \\
\text { HDI/United } \\
\text { States' HDI } \\
\text { ratio 1990 }\end{array}$ & $\begin{array}{c}\text { Country's } \\
\text { HDI/United } \\
\text { States' HDI } \\
\text { ratio 2005 }\end{array}$ & $\begin{array}{c}\text { Relative } \\
\text { change range } \\
1990 / 2005\end{array}$ \\
\hline 12 & $\begin{array}{c}\text { Point of } \\
\text { reference } \\
\text { (US) }\end{array}$ & 0,919 & 0,951 & 1,000 & 1,000 & 0,0000 \\
\hline 53 & Bulgaria & 0,794 & 0,824 & 0,864 & 0,866 & 0,0025 \\
\hline 60 & Romania & 0,777 & 0,813 & 0,845 & 0,855 & 0,0094 \\
\hline
\end{tabular}

Source: HUMAN DEVELOPMENT REPORT 2007/2008. P. 229-230

Table 5. Relative HDI change in Borderland societies and Russian Federation in 1990/2005

\begin{tabular}{|c|c|c|c|c|c|c|}
\hline $\begin{array}{c}\text { HDI Rank } \\
2005\end{array}$ & Country & $\begin{array}{c}\text { HDI } \\
\text { original value } \\
1990\end{array}$ & $\begin{array}{c}\text { HDI } \\
\text { original value } \\
2005\end{array}$ & $\begin{array}{c}\text { Country's } \\
\text { HDI/United } \\
\text { States' HDI } \\
\text { ratio 1990 }\end{array}$ & $\begin{array}{c}\text { Country's } \\
\text { HDI/United } \\
\text { States' HDI } \\
\text { ratio 2005 }\end{array}$ & $\begin{array}{c}\text { Relative } \\
\text { change range } \\
1990 / 2005\end{array}$ \\
\hline 12 & $\begin{array}{c}\text { Point of } \\
\text { reference } \\
\text { (US) }\end{array}$ & 0,919 & 0,951 & 1,000 & 1,000 & 0,0000 \\
\hline 64 & Belarus & 0,790 & 0,804 & 0,860 & 0,845 & $-0,0142$ \\
\hline 67 & $\begin{array}{c}\text { Russian } \\
\text { Federation }\end{array}$ & 0,815 & 0,802 & 0,887 & 0,843 & $-0,0435$ \\
\hline 76 & Ukraine & 0,809 & 0,788 & 0,880 & 0,829 & $-0,0517$ \\
\hline 111 & Moldova & 0,740 & 0,708 & 0,805 & 0,744 & $-0,0607$ \\
\hline
\end{tabular}

Mean $=-0,0425 ; \sigma 2=0,0003$

Source: HUMAN DEVELOPMENT REPORT 2007/2008. P. 229-230

Belarus has better result $(-1,42 \%)$. The worst situation is in Moldova (-6,07 \%). Russian Federation, which is close to Belarus by original HDI value $(0,843$ against 0,845$)$, is more than 3 times worse by relative to the US shift. The mean of relative range value for four post-soviet societies equals $-0,0425, \sigma^{2}=0,0003$. (For three borderland societies Belarus, Moldova, Ukraine it equals -0,0422). The difference with the mean of Central and Eastern European countries that are the EU members is 0,0636 and 0,068 with EU8.

Thus, Eastern Europe was radically reshaped after 15 years of modernization. Different clusters formed in the region by 2005. Poland, Lithuania, Estonia and Latvia were by HDI at the same level of development with Bulgaria and Romania (EU2) remain in the same cell, but they are approaching the cluster of more developed societies Russian Federation and Ukraine in 1990 had considerably higher HDI in 2005. Bulgaria and Romania (EU2), which had lower level of development that Ukraine in 1990, approached the cluster of more developed societies.

Notably, all old EU member-states (EU15) countries displayed positive dynamic in relation to the US. HDI grew more than in the US with the mean of relative range value - 0,0204, $\sigma^{2}=0,0001$. If in 1990 none of the countries had HDI as high as in the US, in 2005 five the EU members exceeded that level. 
United Nations Development Programme (UNDP) changed calculation of HDI and classification parameters of Human development in 2010. Since we use HDI calculated based on 2008 methodology to capture data for 1990's period for several post-soviet countries, it would be logical to keep the former UNDP criterion, according to which High human development should be recognized with the HDI value of 0.800 or above. (Human Development Report, 2008) Following this classification, Belarus and Russian Federation fall into a group of countries of High human development, while only Ukraine and Moldova among selected countries go into a group of Medium human development.

However, if one wants to find real differentiation in Central and Eastern Europe, another working criterion should be employed. It was suggested using UNDP estimation for initial point in 1990 to define clusters showed in Table 1. HDI value of 0,800 equalled 0,8705 of the US HDI in 1990. Apparently, the same value of 0,800 is smaller part of US HDI in 2005 because the latter has increased (in fact, the ratio is 0,841 ). If to keep the same ratio of 0,870 as a benchmark for defining more developed societies as it was in 1990, absolute HDI value would be 0,827 in 2005.
Based on these calculations we can see from Table 6 that all EU8 members fall into a group of more developed societies, while all the rest post-soviet countries concentrate in a cluster of less developed societies. Russian Federation and Ukraine lost their positions and switched to the latter cluster. There are no non-EU countries in the former. Bulgaria and Romania (EU2) remain in the same cell, but they are approaching the cluster of more developed societies.

Therefore, despite the actual growth since 1995, if related to the other societies of the region Ukraine is drastically behind which may lead to the gap in capabilities on the national states scale within Eastern Europe.

\section{Assessment of capabilities and a risk for inclusion in Ukraine}

Comparison with a regional or a group of countries trends is one possible way to assess human development in a modernizing society. Another tool is measurement of the capabilities. Traditional statistical measures often can not be indicative of the actual capabilities and risks for inclusion. As it follows from Table 7, inequality indicators in Ukraine are stable over 8 years and the situation is slightly improving.

However, the average monthly wage statistics demonstrate rising inequality between

Table 6. Differentiation of Central and Eastern Europe in 2005.

\begin{tabular}{|c|c|c|c|}
\hline Status/HDI & More developed (HDI $\geq 0,827)$ & Less developed (HDI <0,827) & $\begin{array}{c}\text { Total number of } \\
\text { countries }\end{array}$ \\
\hline $\begin{array}{c}\text { Non-EU } \\
\text { members }\end{array}$ & 0 & $\begin{array}{c}6 \\
\text { Belarus, Russian Federation, } \\
\text { Ukraine Moldova, } \\
\text { Bulgaria, Romania }\end{array}$ & 6 \\
\hline EU members & $\begin{array}{c}7 \\
\text { Slovenia, Czech Republic, } \\
\text { Hungary, Poland, Lithuania, } \\
\text { Estonia, Latvia }\end{array}$ & 0 & 7 \\
\hline Overall & 7 & 6 & 13 \\
\hline
\end{tabular}

Countries that accessed the EU in 2007 and are approaching a cluster of more developed countries are in italics. 
Table 7. Inequality measures in Ukraine in 1999-2010

\begin{tabular}{|c|c|c|c|c|}
\hline \multirow{2}{*}{ Year } & \multicolumn{2}{|c|}{ Share of income or consumption \% } & \multirow{2}{*}{$\begin{array}{c}\text { Richest } 10 \% \text { to } \\
\text { poorest } 10 \%\end{array}$} & Gini index \\
\cline { 2 - 3 } & Poorest $10 \%$ & Richest $10 \%$ & 6,4 & 29,0 \\
\hline 1999 & 3,7 & 23,2 & 6,0 & 28,2 \\
\hline 2007 & 3,8 & 22,5 & - & 27,6 \\
\hline
\end{tabular}

Source: HUMAN DEVELOPMENT REPORT 2003. P. 283; HUMAN DEVELOPMENT REPORT 2009. P. 196. HUMAN DEVELOPMENT REPORT 2010.

Ukrainian regions and the City of Kyiv (Table 8). The gap between all regions and the capital of Ukraine is growing and 13 of 25 regions therein had an average wage less than $50 \%$ of Kyiv's value (Ukraine's capital) in 2008 ( 0 - in 1995).

National value compared to Kyiv decreased for $14,25 \%$ between 1995 and 2008. The biggest difference for this period have experienced Donetska region - 31,45\%, Dnipropetrovska $29,97 \%$, Zaporizka - 25,05 \%. The smallest changes occurred in Zakarpatska region 2,73\%, Volynska - 8,11\%, Khmelnytska $8,51 \%$. Although the latter regions have average wage less than half of Kyiv's. Remarkably, only 3 regions of 24 (excluding the City of Kyiv and Kyivska region) had the average monthly wages above the national average in 2008.

From a resources perspective the capabilities can be estimated by availability of assets and actual access to them. Even if, for instance, inhabitants of Kyiv have higher wages than population in other regions it doesn't necessarily mean their greater capabilities, for assets can be harder to access in Kyiv because of their higher relative value.

According to the official state statistics, in the last decade Ukrainians obtained on average more financial resources than in the previous period, which implies increase in capabilities. Based on reports of the State Committee of Statistics of Ukraine we calculated that between
1998 and 2008 real salaries in Ukraine grew $309 \%$ (nominal salary increased $1176 \%$ ). Real disposable income since 2001 till 2008 has grown $\mathbf{2 6 3 , 5} \%$. Number of population with average per capita total income under subsistence minimum dropped over 4 and a half times from $\mathbf{3 9 , 2}$ million $(80,2 \%$ of the overall population) in 2001 to $\mathbf{8 , 1}$ million $(18,1 \%$ of the population) in 2008 (official size of subsistence minimum was raised by $231,8 \%$ ) (State Statistics Committee of Ukraine, 2010). These objective statistics indicators are also supported by subjective self-assessment of the population shown in the national representative surveys. Number of people who felt satisfied with their overall position in society increased during 8 years almost 3 times from $7 \%$ in 1998 to $20,2 \%$ in 2006 (Panina et al., 2006).

These data makes to assume that in average the capabilities of the population in Ukraine improved. However, this assumption may not embrace all set of the capabilities. As an example, we will explore such a vital capability as housing.

In 2001 according to the survey of the Institute of Sociology of NAS of Ukraine 36,7 \% of the respondents lived in a private apartment owned by their families and 35,6\% lived in a private house (part of the house) which were in possession of their families (Panina et al., 2006). Hence, over $72 \%$ of Ukrainians could feel secure with regard to their access to housing. 
Table 8. National and regional average monthly wages as percentage of the City of Kyiv average monthly wage in $1995-2008$

\begin{tabular}{|c|c|c|c|c|}
\hline & 1995 & 1998 & 2003 & 2008 \\
\hline Ukraine & 73,00 & 61,94 & 60,71 & 58,75 \\
\hline $\begin{array}{l}\text { Autonomous } \\
\text { Republic of Crimea }\end{array}$ & 70,00 & 57,89 & 56,90 & 52,34 \\
\hline Vinnytska & 58,00 & 46,56 & 43,89 & 45,67 \\
\hline Volynska & 53,00 & 42,51 & 41,92 & 44,89 \\
\hline Dnipropetrovska & 91,00 & 76,52 & 69,12 & 61,03 \\
\hline Donetska & 97,00 & 78,95 & 72,27 & 65,55 \\
\hline Zhytomyrska & 61,00 & 47,77 & 43,89 & 45,67 \\
\hline Zakarpatska & 50,00 & 43,72 & 49,80 & 47,27 \\
\hline Zaporizka & 84,00 & 74,09 & 71,09 & 58,95 \\
\hline Ivano-Frankivska & 65,00 & 48,58 & 52,83 & 50,20 \\
\hline Kyivska & 78,00 & 61,13 & 61,76 & 60,25 \\
\hline Kirovogradska & 58,00 & 48,18 & 46,39 & 46,45 \\
\hline Luganska & 82,00 & 65,99 & 62,29 & 57,55 \\
\hline Lvivska & 62,00 & 53,44 & 55,06 & 51,07 \\
\hline Mykolayvska & 68,00 & 58,70 & 61,76 & 52,73 \\
\hline Odeska & 66,00 & 59,11 & 59,66 & 53,12 \\
\hline Poltavska & 76,00 & 60,73 & 57,42 & 54,03 \\
\hline Rivnenska & 61,00 & 48,58 & 51,25 & 49,54 \\
\hline Sumska & 66,00 & 52,63 & 49,80 & 47,89 \\
\hline Ternopilska & 53,00 & 42,11 & 39,95 & 42,71 \\
\hline Kharkivska & 72,00 & 64,37 & 59,79 & 54,62 \\
\hline Khersonska & 59,00 & 50,61 & 46,78 & 44,73 \\
\hline Khmelnytska & 55,00 & 46,15 & 42,44 & 46,49 \\
\hline Cherkaska & 63,00 & 51,42 & 45,99 & 47,46 \\
\hline Chernivetska & 55,00 & 42,91 & 45,20 & 45,61 \\
\hline Chernigivska & 57,00 & 49,39 & 44,94 & 44,57 \\
\hline City of Kyiv & 100,00 & 100,00 & 100,00 & 100,00 \\
\hline
\end{tabular}

Source: State Statistics Committee of Ukraine, 2010. (Wage accruals per pay-roll, UAH) Percentages calculated by the author.

The State Statistics Committee of Ukraine has reported that since 2000 till 2008 overall $\mathbf{6 7 2}$ thousand apartments have been put into service with total size of 68753 sq. $\mathrm{m}$ and number of apartments built per 1000 population have risen from $\mathbf{1 , 3}$ in 2000 to $\mathbf{2 , 0}$ in 2008; there were $\mathbf{2 2 , 8}$ sq. $\mathbf{m}$ average per 1 inhabitant in 2008 compared to 20,2 sq. $\mathbf{m}$ in 1998 (State Statistics Committee of Ukraine, 2010).
Average room number for a dwelling was $\mathbf{2 , 8}$ in 2006 compared to 2,6 in 1998, and in average a room was shared by $\mathbf{1 , 7}$ inhabitants in 2006 compared to 2,0 in 1998 (Panina et al., 2006).

Number of families and single persons registered as requiring municipal or cooperative accommodations declined from $\mathbf{2}$ million and 29 thousand in 1998 to $\mathbf{1}$ million and 216 thousand in 2008 (State Statistics Committee of Ukraine, 
2010). Notably, that during the same period there were only 245 thousand families and single persons who obtained municipal or cooperative accommodations (State Statistics Committee of Ukraine, 2010).

These official statistics and the survey data depict the situation with housing for Ukrainians as stable and slightly improving. But what is the capability for a common Ukrainian to acquire their own housing during life? We calculate such capability as number of years needed for a family of two fulltime working persons to earn an amount to purchase a $50 \mathrm{sq}$. $\mathrm{m}$ apartment for a current market price on the secondary residential market in a particular region. Number of years is calculated based on the average monthly wage for a particular region assuming that the whole wage amount before paying taxes of one family member is intended for the purchase.

Table 9 demonstrates that in Desnianskyi district of the City of Kyiv, which has had the lowest prices on the secondary residential market in Kyiv persistently over decade, capability to purchase a modest apartment implies saving the whole monthly wage (without even paying taxes) for virtually the same period of 12 years in 1998 and 2003.
This period became almost one and a half time longer at the beginning of 2008 and reached 17 years. Meanwhile, the average monthly wage in Kyiv increased over 3 times between 1998 and 2003 and more than 4 times between 2003 and 2008 .

The actual situation with housing capabilities in Kyiv is even more constrained. We calculated the price of a 50 sq. $\mathrm{m}$ apartment based on an average price of $1 \mathrm{sq} . \mathrm{m}$ in the district. However, smaller apartments normally have higher price for a 1 sq. $\mathrm{m}$ on the residential market. Besides, we selected the district with the price minimum in the city.

Table 10 presents calculations for Sviatoshinskyi district, in which prices of 1 sq. $\mathrm{m}$ were close to median for Kyiv in the considered interval.

The period needed to earn a required amount was with some fluctuation about 13 years in 1998 and 2003. But it exceeded 19 years in 2008. The difference with the district with the minimal price became more significant over two years. According to SVDevelopment consulting company database the mean price for 1 sq. $m$ in 2008 for the City of Kyiv was 3523 USD. Consequently, an apartment for the mean price would demand over $\mathbf{2 3}$ years of earnings.

Table 9. Market prices for a sq. $\mathrm{m}$ on the secondary residential market, average monthly wages and number of years expected to purchase a 50 sq. m apartment in Desnianskyi district of the City of Kyiv in 1998-2008

\begin{tabular}{|l|c|c|c|}
\hline & January 1998 & January 2003 & January 2008 \\
\hline Sq. m price in USD & 366 & 414 & 2490 \\
\hline UAH/USD official exchange rate & 1,91 & 5,33 & 5,05 \\
\hline Sq. m price in UAH & 699,06 & 2206,62 & 12574,5 \\
\hline Calculated price of 50 sq. m apartment in UAH & 34953 & 110331 & 628725 \\
\hline $\begin{array}{l}\text { Monthly wage in the City of Kyiv } \\
\text { (Wage accruals per pay-roll, UAH) }\end{array}$ & 247 & 761 & 3074 \\
\hline Number of years expected to purchase an apartment & 11,8 & 12,0 & 17,0 \\
\hline
\end{tabular}

Sources: Association of Real Estate Specialists of Ukraine (ASNU, 2010), State Statistics Committee of Ukraine, 2010, National Bank of Ukraine. Calculations made by the author. 
Table 10. Market prices for a sq. $\mathrm{m}$ on the secondary residential market, average monthly wages and number of years expected to purchase a 50 sq. m apartment in Sviatoshinskyi district of the City of Kyiv in 1998-2008

\begin{tabular}{|l|c|c|c|}
\hline & January 1998 & January 2003 & January 2008 \\
\hline Sq. m price in USD & 411 & 441 & 2810 \\
\hline UAH/USD official exchange rate & 1,91 & 5,33 & 5,05 \\
\hline Sq. m price in UAH & 785,01 & 2350,53 & 14190,5 \\
\hline Calculated price of 50 sq. m apartment in UAH & 39250,5 & 117526,5 & 709525 \\
\hline $\begin{array}{l}\text { Monthly wage in the City of Kyiv } \\
\text { (Wage accruals per pay-roll, UAH) }\end{array}$ & 247 & 761 & 3074 \\
\hline Number of years expected to purchase an apartment & 13,2 & 12,9 & 19,2 \\
\hline
\end{tabular}

Sources: Association of Real Estate Specialists of Ukraine (ASNU, 2010), State Statistics Committee of Ukraine, 2010, National Bank of Ukraine. Calculations made by the author.

Table 11. Average monthly wages, market prices for a sq. $\mathrm{m}$ on the secondary residential market and number of years expected to purchase a 50 sq. $\mathrm{m}$ apartment in five Ukrainian cities in 2003-2008

\begin{tabular}{|c|c|c|c|c|c|c|c|c|}
\hline & \multicolumn{2}{|c|}{ 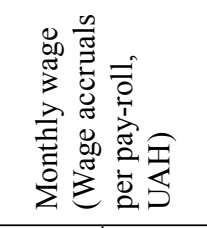 } & \multirow[t]{2}{*}{ 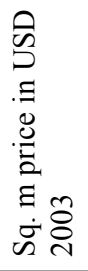 } & \multirow[t]{2}{*}{ 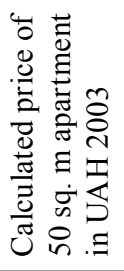 } & \multirow{2}{*}{ 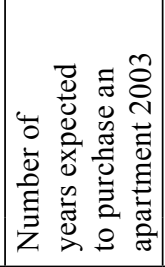 } & \multirow[t]{2}{*}{ 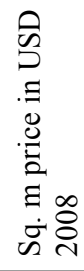 } & \multirow[t]{2}{*}{ 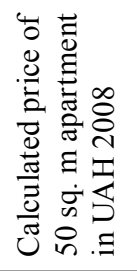 } & \multirow{2}{*}{ 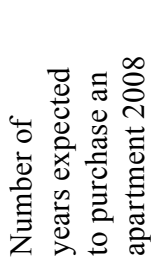 } \\
\hline & 2003 & 2008 & & & & & & \\
\hline Dnipropetrovsk & 526 & 1876 & 380 & 101270 & 16,0 & 2365 & 597162,5 & 26,5 \\
\hline Donetsk & 550 & 2015 & 400 & 106600 & 16,2 & 2451 & 618877,5 & 25,6 \\
\hline Lviv & 419 & 1570 & 488 & 130052 & 25,9 & 3020 & 762550 & 40,5 \\
\hline Odesa & 454 & 1633 & 480 & 127920 & 23,5 & 2992 & 755480 & 38,6 \\
\hline Kharkiv & 455 & 1679 & 341 & 90876,5 & 16,6 & 2120 & 535300 & 26,6 \\
\hline
\end{tabular}

Sources: State Statistics Committee of Ukraine, 2010, National Bank of Ukraine, SVDevelopment Consulting Company Database. Calculations made by the author.

With the mean price of 568 USD for 1 sq. $m$ it was

\section{$\mathbf{1 6 , 5}$ years in 2003 .}

Since there is the lack of data on real estate prices in Ukrainians regions, it was possible to calculate the index for several big cities only and for a shorter period.

Table 11 shows that despite lower prices on the secondary residential market comparing to the City of Kyiv, the capability to purchase own apartment became poorer in all big Ukrainian regional cities in 2008. However, it is possible to divide them in two clusters by the indicator of years expected to purchase an apartment. The first one embraces three cities - Dnipropetrovsk, Donetsk and Kharkiv which with the City of Kyiv (16,5 years) fell within range from 16 to 16,6 years in 2003 . The values increased by $9,4-10,5$ years by 2008 with the range $\mathbf{2 5 , 6} \mathbf{- 2 6 , 6}$ years. Remarkably, the value in Kyiv (23 years) was lower by 2,6 years than in Donetsk and 3,6 than in Kharkiv in 2008.

The second cluster of cities Odesa and Lviv had considerably higher values of 23,5 -and 25,9 years in 2003 (one third longer period than in the first cluster). In 2008 they reached point of $\mathbf{3 8 , 6}$ and 40,5 years accordingly. (The difference of 
approximately one third with the other cluster was kept. The difference with Kyiv grew to over $40 \%$.) Although prices on the secondary residential market in the regional cities from both clusters were very similar: mean 417,8 (USD per 1 sq. m), standard deviation 57,3 and the coefficient of variation 0,137 in 2003; and mean 2589,6 (USD per 1 sq. m), standard deviation 357,03 and the coefficient of variation 0,138 in 2008, disparity in the capability indicator was determined by lower monthly wages in Lviv and Odesa regions which concurred with relatively more expensive housing.

Thus, foregoing calculations demonstrate the actual and significant decrease of the capability to acquire own housing in the biggest Ukrainian cities including the national capital. Meanwhile other relevant statistical indicators and survey self-reports failed to reveal the negative trend in housing capabilities.

\section{Conclusion}

This study provides a critical observation of development of Ukraine as a modernizing East European society in comparative perspective. Employing the capability approach to social inclusion allows assessment of the access to the resources, hidden risks for inclusion and implicit indicators of inequality. From this perspective social inclusion is an important factor in human development which embraces the means of providing and securing human choice.

This paper shows that despite the actual growth of GDP per capita, real disposable income and Human Development Index since 1995, if compared to other societies of the region that had similar level of development Ukraine is significantly behind which implies the growing lag in capabilities on the national states scale within Eastern Europe. In particular, within a decade the access to housing in Ukraine, which was already very poor in 1998, dramatically worsened in the 2000's.

The study is focused on the selected case of the relative access to the resources in the period of economic growth in conjunction with comparison of developmental tracks in Eastern Europe based on conventional HDI methodology. It unveils limitations of indicators of official statistics and available data from traditional surveys. The capabilities model can supplement existing methods of measurement of social development in sociology. The capabilities, which are allocated for social actors and groups, determine their actual choices. The choice application requires social inclusion of actors. Relative access to the resources, recognition, participation, values as motives of action and choice, and institutional means of securing choice can be considered dimensions of modernization which induces a gain in capabilities.

\section{Acknowledgements}

Research for this article was supported in part by the Carnegie Research Fellowship Program, which is administered by the National Council for Eurasian and East European Research (NCEEER). The opinions expressed herein are the author's own and do not necessarily express the views of either the Carnegie Corporation of New York or NCEEER.

A version of this paper was presented at $81^{\text {st }}$ Annual Meeting of Eastern Sociological Society (ESS), Philadelphia, USA, 24-27 February 2011 and some materials were used in a paper "European Integration and Trends of Development of Eastern European Borderland", Proceedings of National University of "Kyiv-Mohyla Academy", Vol. 122, 2011.

The author is grateful to Dr. Brian Gareau (Boston College, USA) for his valuable comments. 
Relation Turkey to European civilization is under discussion that is omitted in this paper. Russian Federation has a special position that will be discussed below.

2 Modernization rhetoric was used in official documents and presidents' addresses of both countries, е.g.: Послание Президента Федеральному Собранию Российской Федерации. - 12 ноября 2009 года, Москва, Большой Кремлёвский дворец. - Available at: http://news.kremlin.ru/transcripts/5979; Послание Президента Федеральному Собранию Российской Федерации. - 22 декабря 2011 года, Москва, Кремль. - Available at: http://news.kremlin.ru/ news/14088; Модернізація України - наш стратегічний вибір : Щорічне Послання Президента України до Верховної Ради України. - К., 2011. - 416 c.- Available at:http://www.president.gov.ua/docs/Poslannya_sborka.pdf; Тільки глибока модернізація України сприятиме її швидкому розвитку : Виступ Президента України на урочистостях з нагоди відзначення 80-річчя утворення Дніпропетровської області. - 24.02.2012. - Available at: http://www.president.gov. ua/news/23092.html

3 Slovakia was excluded because of lack of the data. Russian Federation was added as a point of reference.

\section{References}

1. Acemoglu D., Robinson J.A. (2012) Why Nations Fail: The Origins of Power, Prosperity, and Poverty. New York: Crown Publishers.

2. Alexander J. (1980) Core Solidarity Ethnic Outgroup, and Social Differentiation: A Multidimensional Model of Inclusion in Modern Societies: In J..Dofny, A.Akiwowo (eds.).National and ethnic movements. Beverly Hills, Calif. \& London. Sage Publications: 5-28.

3. Allard, E. (2002) Somnitelnye dostoinstva kontseptsii modernizatsii [Questionable merits of the concept of modernization], Sotsiologicheskie Issledovania, No. 9, pp. 60-66.

4. Anand S., Sen A. (1994) Human Development Index: Methodology and Measurement. New York : Human Development Report Office.

5. Andjelkovič et al. (2011) Ot transformatsii $k$ obshchestvu dlya vsekh: Regional'nyi doklad o chelovecheskom razvitii. Bratislava: PROON [Transformation of a society for all: Regional report on human development]: Bratislava: UNDP. Available at: http://www.undp.tj/files/Regional_Human Development_Report_Beyond_transition_towards_inclusive_societies_RUS.pdf

6. ASNU (2010) Assotsiatsiya spetsialistov po nedvizhimosti (rieltorov) Ukrainy (ASNU) [Association of real estate professionals (realtors) Ukraine] Available at http://www.asnu.net/ analitica08-1.php

7. Blokker P. (2005) Post-Communist Modernization, Transition Studies, and Diversity. Europe European Journal of Social Theory 8(4): 503-525.

8. Cohen S. F. (2001) Failed Crusade: America and the Tragedy of Post-Communist Russia. New York: W.W.Norton \& Co.

9. Comim F. et al. (2008) The Capability Approach: Concepts, Measures and Applications. Cambridge University Press.

10. Dworkin R. (2002) Sovereign Virtue: The Theory and Practice of Equality. Harvard University Press.

11. Esping-Andersen G. (2007) Sociological Explanations of Changing Income Distributions. American Behavioral Scientist 50: 639-658.

12. European Commission (2007) Official web site. Available at: http://ec.europa.eu/enlargement/ countries/index_en.htm

13. Foster J, Sen A. (1997) On Economic Inequality. Oxford: Clarendon Press - Oxford University Press.

14. Fraser N. (2007) Identity, Exclusion, and Critique: A Response to Four Critics, European Journal of Political Theory 6(3) 305-338. 
15. Honneth A. (2001) Recognition or Redistribution?: Changing Perspectives on the Moral Order of Society, Theory, Culture \& Society 18(2-3): 43-55

16. Human Development Report 2003. UNDP.

17. Human Development Report 2007/2008. UNDP.

18. Human Development Report 2009. UNDP.

19. Human Development Report 2010. UNDP.

20. ISA (2006) The Quality of Social Existence in a Globalizing World. XVI World Congress of Sociology Programme. Durban: ISA.

21. Kapustin B. (2003) Modernity's Failure/Post-modernity's Predicament: The Case of Russia. Critical Horizons 4: 99-145.

22. Knöbl W. (2003) Theories That Won't Pass Away: The Never-ending Story of Modernization Theory: In Gerard Delaty and Engin F. Isin (eds) Handbook of Historical Sociology. London: Sage Publications: 96-107.

23. Kuklys W. (2005) Amartya Sen's Capability Approach: Theoretical Insights and Empirical Applications. Springer.

24. Lamont M. (2009) Responses to Racism, Health, and Social Inclusion as a Dimension of Successful Societies: In Peter A. Hall, Michele Lamont (eds.) Successful Societies: How Institutions and Culture Affect Health. Cambridge, Cambridge University Press: 151-168.

25. Martinetti E.C. (2000) A multidimensional assessment of well-being based on Sen's functioning approach. Revista Internazionale di Scienze Social 108: 207-239.

26. National Bank of Ukraine. Available at http://www.bank.gov.ua/KURS/last_kurs1.htm

27. Nussbaum M, Sen A. (eds.) (1993) The Quality of Life. Oxford: Clarendon Press, 1993.

28. Panina N. et al. (2006) Українське сусільство: соціологічний моніторинг 1994-2006 / За ред. Н.В.Паніної. - К.: Інститут соціоло-гії НАН України / Ukrainian Society: Sociological Monitoring 1994-2006. - Kiev: Institute of Sociology of NAS of Ukraine, 2006.

29. Parsons T. (1966) Societies: evolutionary and comparative perspectives. Englewood Cliffs, N.J.: Prentice-Hall.

30. Parsons T. (1977) The evolution of societies. Englewood Cliffs, N.J.: Prentice-Hall.

31. Sachs J.D. (2008) Common Wealth: Economics for a Crowded Planet. London: Penguin Books.

32. Schwartz et al. (2001) Extending the Cross-Cultural Validity of the Theory of Basic Human Values with a Different Method of Measurement. Journal of Cross-Cultural Psychology September 32 (5): 519-542.

33. Sen A. (1999) Development as Freedom. Oxford: Oxford University Press.

34. Srinivasan T. N. (1994) Human development: A new paradigm or reinvention of the wheel? The American Economic Review. 84(2): 238-243.

35. State Statistics Committee of Ukraine (2010). Date of the Last modifications: 19/01/2010. Available at http://ukrstat.gov.ua/

36. Stiglitz J., Sen A., Fitoussi J-P. (2009) Report by the Commission on the Measurement of Economic Performance and Social Progress. Available at: http://www.stiglitz-sen-fitoussi.fr/documents/ rapport_anglais.pdf

37. Sugden R. (1993) Welfare, resources, and capabilities: A review of Inequality Re-examined by Amartya Sen. Journal of Economic Literature 31 (4): 1947-1962. 
38. SVDevelopment consulting company. Available at http://www.svdevelopment.com/ru/web/ flat_costs/

39. Sztompka P. (1996) Sotsiologia sotsialnyh izmenenii [Sociology of social change]. Translated from English, ed. by V.A. Yadov. M.: Aspect Press, 1996. 416 p.

40. Welzel C., Inglehart R., Klingemann H-D. (2003) The theory of human development: A crosscultural analysis. European Journal of Political Research. 42: 341-379.

41. Wilson L. (2006) Developing a Model for the Measurement of Social Inclusion and Social Capital in Regional Australia. Social Indicators Research. 75(3): 335-360.

42. Yusuf S. et al. (2009) Development economics through the decades: a critical look at 30 years of the world development. Washington, D.C.: World Bank.

\title{
Критическая оценка развития
}

\section{модернизирующегося общества в Восточной Европе: скрытые риски для социальной включенности}

Ю.Б. Савельев

Киевский наџиональный университет им. Т. Шевченко Украина, 01601, Киев, ул. Володимирская, 60

\begin{abstract}
Возможностный подход предложил понимать человеческую свободу как возможность выбора различных альтернативных вариантов (Foster and Sen, 1997). Рост возможностей является основой развития человеческого потенциала (Sen, 1999) и важнейшей частью проиесса модернизации (Welzel, Inglehart and Klingemann, 2003). В статье предлагается возможностная модель сочиальной включенности, которая используется для оценки человеческого развития модернизирующегося общества. Она также позволяет выявить скрытые риски неравенства и эксклюзии. Обосновывается, что, несмотря на быстрый экономический рост, фактическое увеличение реальных доходов на душу населения и улучшение индекса развития человеческого потенциала в Украине с конца 1990-х до середины 2000-х годов, возможности граждан были под серьезной угрозой. Украина отставала в развитии от других обществ региона (за исключением Молдовы ), хотя уровни развития стран Восточной Европы были очень похожи в начале 1990-х годов. Используемый подход демонстрирует растущий разрыв в возможностях социальных акторов в регионе.
\end{abstract}

Ключевые слова: сочиальная включенность (инклюзия), модернизация, развитие, возможности, Восточная Европа, Украина.

Научная специальность: 22.00.00 - социология. 